\title{
THE MICRO-DETERMINATION OF GOLD IN BIOLOGICAL FLUIDS AND TISSUES
}

\author{
BY \\ WALTER D. BLOCK \\ From the Rackham Arthritis Research Unit, ${ }^{*}$ Medical School, University of Michigan, Ann Arbor
}

(Received for Publication Sept. 6, 1944)

The increasing interest in the use of gold salts as chemotherapeutic agents in the treatment of certain diseases (Hartfall, et al., 1937) has made apparent the necessity of an accurate, specific, and sensitive method for the determination of gold in various biological materials. Moreover, the lack of information regarding the metabolism and pharmacology of this element further emphasizes this need. Previous methods have employed either an electrolytic precipitation, a colorimetric reaction, or a titrimetric procedure. The electrolytic methods such as those of Cadwell and Leavell (1919), and Lombolt (1926), involve too many technical difficulties to be of practical value. The numerous colorimetric methods (Stanbury, 1932; Leulier, Bernard, and Loisy, 1937) lack both specificity and accuracy. The method of Merejkovsky (1933) seems to be specific and is probably the best, but the large blank from the reagent itself and the inadequate directions of the author make it impossible to duplicate the original results. The iodometric titration first employed by Peterson (1898) and modified most recently by Hansborg (1925) cannot be applied to tissues and blood because the ferric iron present in these substances interferes with the reaction. This difficulty has been overcome by Tukats (1933) by a preliminary precipitation of the gold with oxalic, acid. However, this preliminary procedure makes it impossible to apply the method to the determination of very small quantities of gold. Pollard (1937) determined gold after conversion to the chloride by titration with hydroquinone using o-dianisidine as an indicator. In order to secure quantitative results it was necessary for other inorganic salts to be absent. This condition was obtained by a preliminary precipitation of the gold from the original substance by use of a hydrochloric acid solution of tellurium saturated with sulphur trioxide. A modification of this method for use with urine (Jamieson and Watson, 1938) required large volumes of urine and was limited in sensitivity.

Because none of these methods are entirely adequate, it was thought it would be of value to

* The Rackham Arthritis Research Unit is supported by the Horace H. Rackham School of Graduate Studies of the University of Michigan. develop an accurate and specific modification of Pollard's (1937) procedure for the quantitative determination of gold in small amounts of blood, urine, and tissue.

\section{Principle of Present Method}

The present method involves the determination of gold by the use of the colour reaction produced by dianisidine and auric chloride in a slightly acid solution buffered with potassium bifluoride. This colour production follows Beer's law and can be quantitatively measured in an Evelyn photoelectric colorimeter. Preliminary digestion by use of sulphuric acid and hydrogen peroxide is necessary to oxidize all interfering organic substances. Since the colour reaction is specific for the chloride or bromide of gold, it is necessary to convert the separated gold to the chloride by aqua regia. All excess sulphuric acid must be previously removed by evaporation to absolute dryness in order to secure a quantitative conversion of gold to the chloride. Likewise after conversion to the chloride, excess aqua regia must be removed because nitrosyl chloride as well as nitric acid produces a colour with dianisidine. Further, the presence of any excess acid will inhibit the production of the final colour with gold chloride. Potassium fluoride and hydrochloric acid are then added to the solution to produce the buffered acid solution. In addition, the fluoride is necessary to prevent the reaction of any ferric iron present with the dianisidine (Kul'berg, 1936).

\section{Experimental REAGENTS}

Standard gold solution.-199.84 mg. of gold chloride $\left(\mathrm{AuCl} \mathrm{C}_{3} \cdot \mathrm{HCl} \cdot 3 \mathrm{H}_{2} \mathrm{O}\right.$ (Merck and Company)) are transferred to a $1000-\mathrm{c} . \mathrm{cm}$. volumetric flask and diluted to volume with distilled water. $1 \mathrm{c} . \mathrm{cm}$. of this solution is equivalent to $0 \cdot 1 \mathrm{mg}$. of gold. This stock standard is stable for two to three days.

Potassium fluoride.-10 g. of this salt are weighed out accurately and transferred to a $100-\mathrm{c} . \mathrm{cm}$. volumetric flask and diluted to volume with distilled water. After the salt dissolves, the solution is filtered. This solution is stable for two days.

Potassium bifluoride.-(Merck and Company). 0.75 g. of potassium bifluoride are weighed accurately and trans- 
ferred quantitatively to a $100-\mathrm{c} . \mathrm{cm}$. volumetric flask and diluted to volume with distilled water. This solution should be made fresh every 12 hours.

Dianisidine.-(Technical. Eastman Kodak Company). $250 \mathrm{mg}$. of dianisidine are weighed accurately, transferred to a $250-\mathrm{c} . \mathrm{cm}$. volumetric flask, and $150 \mathrm{c.cm}$. of water and $1 \mathrm{c} . \mathrm{cm}$. of concentrated hydrochloric acid are added. The solution is then diluted to volume with distilled water and will remain stable for one day.

Hydrochloric acid (1:4).-25 c.cm. of concentrated hydrochloric acid are transferred to a $100-\mathrm{c} . \mathrm{cm}$. volumetric flask and diluted to volume with distilled water.

Hydrochloric acid $(1: 12)$. $-41.5 \mathrm{c} . \mathrm{cm}$. of concentrated hydrochloric acid are transferred to a $500-\mathrm{c} . \mathrm{cm}$. volumetric flask and diluted to volume.

Aqua regia.-10 c.cm. of concentrated nitric acid are added to $30 \mathrm{c.cm}$. of concentrated hydrochloric acid. This solution should be made every day.

\section{PROCEDURE}

A known amount of urine ( 10 to $50 \mathrm{c.cm}$.) is placed in a Kjeldahl flask * which has been graduated to $100 \mathrm{c.cm}$. To this flask 3 to $5 \mathrm{c} . \mathrm{cm}$. of concentrated sulphuric acid are added. A small glass bead and several drops of caprylic alcohol are introduced into the mixture, which is then slowly heated on a Kjeldahl digestion rack until the solution begins to char. The heating is continued for 15 to 20 minutes, after which the flask is cooled and a 30 per cent. solution of hydrogen peroxide (superoxol) is added drop by drop until the solution is water clear. This requires approximately 15 to 20 drops. The solution is then evaporated to complete dryness over a micro-burner. The sulphuric acid fumes are removed by inserting into the neck of the flask a glass tube which is connected through a water trap to a water pump. The flask is cooled, 2 c.cm. of aqua regia are added, and the flask is heated on a micro-burner until the solution is evaporated to 0.2 to $0.3 \mathrm{c} . \mathrm{cm}$. The flask is removed, and while still warm a slow stream of air is introduced into the flask, which evaporates the remaining acid and moisture. During the heating the flask should be 5 to $6 \mathrm{~cm}$. above the tip of the flame to avoid local overheating, which will decompose the gold chloride. After cooling, the precipitated inorganic salts are redissolved by addition of about $75 \mathrm{c} . \mathrm{cm}$. of distilled water. $0.75 \mathrm{c} . \mathrm{cm}$. of hydrochloric acid (1:4), $8 \mathrm{c.cm}$. of potassium fluoride, and $1 \mathrm{c} . \mathrm{cm}$. of dianisidine solution are added to the flask. The volume is made up to $100 \mathrm{c} . \mathrm{cm}$. with distilled water, the flask stoppered, and the solution thoroughly mixed The solution is then transferred to a colorimeter absorption tube, the tube being filled to within 1 to $2 \mathrm{~cm}$. of the top. After stoppering, the pink colour, which reaches its maximum intensity within 5 to 10 minutes, is read in the Evelyn photoelectric colorimeter, using filter number 440 with a centre setting on the galvanometer of 76 . The stoppering of the graduated Kjeldahl flask and absorption tube is necessary to prevent a slight colour development of the reagents in the presence of air.

The same procedure can be applied to blood, using 1 to $5 \mathrm{c.cm}$. of plasma: this is placed in a micro-Kjeldahl digestion tube which has been graduated to a $15 \mathrm{c} . \mathrm{cm}$. volume. The initial digestion requires $1 \mathrm{c} . \mathrm{cm}$. of sulphuric acid, and the conversion to the chloride is accomplished by $0.5 \mathrm{c} . \mathrm{cm}$. of aqua regia. The colour is then developed by the addition of $0.1 \mathrm{c} . \mathrm{cm}$. of hydrochloric acid $(1: 12), 1 \mathrm{c} . \mathrm{cm}$. of potassium bifluoride, and $0.4 \mathrm{c} . \mathrm{cm}$.

* 100-c.cm. Kjeldahl flasks with necks shortened to $506 \mathrm{~cm}$. are the size used, as when they are accurately calibrated with a Bureau of Standards 100 -c.c. pipette the calibration mark falls in the narrow neck portion of the flask. of dianisidine. This is then diluted to $15 \mathrm{c} . \mathrm{cm}$. graduation and the colour read as in the case of the urine. Stoppering of the Kjeldahl flask and absorption tube is unnecessary because the potassium bifluoride prevents the production of any colour of the reagents in the presence of air

The tissue $(0.5$ to $10 \mathrm{~g}$.) to be analysed is placed in an accurately calibrated 100 -c.cm. Kjeldahl flask whose neck has been shortened to 5 or $6 \mathrm{~cm}$. 10 to $20 \mathrm{c.cm}$. of concentrated nitric acid and a few drops of caprylic alcohol are added and the tissue allowed to stand for a few hours until solution has occurred. 10 to $15 \mathrm{c.cm}$. of concentrated sulphuric acid are introduced into the flask, which then is heated on a Kjeldahl digestion rack until the tissue is thoroughly charred. After the digest is cooled, a 30 per cent. solution of hydrogen peroxide (superoxol) is added drop by drop until the solution is water clear. The solution is evaporated to dryness over a micro-burner. The sulphuric acid fumes are removed by inserting into the neck of the flask a glass tube which is connected through a water trap to a water pump. The contents of the flask are then treated with aqua regia to convert the gold to the chloride. If the tissues contain amounts of gold less than 200 micrograms, the colour is developed and read as previously described directly with the entire contents of the digestion flank. However, if larger amounts of gold are present the aqua regia solution in the flask is heated to boiling, cooled, and transferred to a 100-c.cm. volumetric flask. The Kjeldahl flask is rinsed twice with 15 to $20 \mathrm{c.cm}$. of boiling aqua regia, and the washings are added to the volumetric flask, which is made to volume with distilled water. Aliquots containing 50 to 150 micrograms of gold are transferred to the shortened graduated 100-c.cm. Kjeldahl flasks, evaporated to dryness, remaining traces of sulphuric acid being removed as before, and the gold reconverted to auric chloride by boiling with aqua regia. The aqua regia solution of this aliquot is then used to develop the colour. Any fatty or muscular tissue (legs, gastro-intestinal tract) is treated in the same fashion, except that the digestion is carried out in a $300-\mathrm{c} . \mathrm{cm}$. Kjeldahl flask with the addition of selenium as a catalyst. After evaporation to dryness with complete removal of the sulphuric acid, the residue is put into solution by boiling with three $40-\mathrm{c} . \mathrm{cm}$. portions of aqua regia. All the washings are collected in a $250-\mathrm{c} . \mathrm{cm}$. volumetric flask, made to volume with water, and aliquots containing 50 to 150 micrograms of gold transferred to the special $100 \mathrm{c.cm}$. Kjeldahl flasks. The procedure is then carried out as described above for $D$ urine.

This same procedure can be applied to large organs or carcasses of small experimental animals as well as to $\Omega$ dried animal and human faeces, the only modification $N$ being that a $500-\mathrm{c} . \mathrm{cm}$. Kjeldahl digestion flask is used.

Special attention should be called to the amount of $\sigma$ $1: 4$ hydrochloric acid added in the colour reaction, for the rate of colour development and fading depends upon the ratio of fluoride to acid. The amount of acid which $\mathbb{\Phi}$ remains in the flasks after conversion with aqua regia? depends upon the amount of inorganic salts present. A maximum colour will develop in 6 to 8 minutes if $0.75 \mathrm{c} . \mathrm{cm}$. of $1: 4$ hydrochloric acid is used in direct determination of gold in tissues or urine. In determina- $\mathbb{D}$ tions of gold in carcases or faeces, $1.25 \mathrm{c} . \mathrm{cm}$. of the acid must be added and $2.5 \mathrm{c} . \mathrm{cm}$. in the case of diluted tissue digests. It is best to read the colour at one-minute intervals during the development until the maximum colour is reached and fading begins. Since it requires only 15 seconds to make a reading, four tubes may be read easily at minute intervals. 
Results obtained in Tests with Pure Solutions of Gold Chloride

A series of determinations were conducted using varying quantities of gold ranging from 5 to 300 micrograms. The results are presented in Table 1. When the galvanometer was adjusted to 100 , a stoppered tube containing an aliquot of the blank solution made up of $3 \mathrm{c} . \mathrm{cm}$. of hydrochloric acid (1:4), $8 \mathrm{c.cm}$. of potassium fluoride, and $1 \mathrm{c.cm}$. of dianisidine diluted to $100 \mathrm{c.cm}$. volume, a centre setting of $76^{1}$ was obtained as compared to $76^{\circ}$ when water alone was used. The ratio of photometric density ("L values") to the concentration of the test solution is a constant ( $\mathrm{K}$, Table 1$)$. Reproducibility of results in these tests was excellent. Below the quantity of 5 micrograms of gold there is a significant deviation from the " $K$ value." However, this can be overcome in unknowns by using sufficiently large samples of the substance to give readings in the range of 5 to 300 micrograms, which was the range desired in urine. For blood, however, the desirable range was 5 to 30 micrograms. The blank solution for blood which was diluted to $15 \mathrm{c} . \mathrm{cm}$. contained $0 \cdot 1 \mathrm{c} . \mathrm{cm}$. of hydrochloric acid (1: 12), $1 \mathrm{c.cm}$. of potassium bifluoride, and $0.4 \mathrm{c.cm}$. of dianisidine solution, gave a centre setting of $76^{\circ}$. The " $\mathrm{K}$ value" determined for the range (5 to 30 micrograms) was constant, averaging 0.020 (0.019 to 0.022 ).

TABLE 1

Reproducibility of the Chemical Method for the Determination of Gold Chloride and the Constancy of the Ratio of Photometric Density to Concentration of the Compound.

\begin{tabular}{|c|c|c|c|c|}
\hline $\begin{array}{c}\text { Gold } \\
\text { present }\end{array}$ & $\begin{array}{l}\text { Number } \\
\text { of tests }\end{array}$ & $\begin{array}{l}\text { Range of } \\
\text { galvanometer } \\
\text { readings } 1\end{array}$ & $\begin{array}{c}\text { Average } \\
\text { photometric } \\
\text { density } 2 \\
\text { (" } \mathrm{L} \text { values") }\end{array}$ & $\begin{array}{l}\text { Calculated } \\
\mathrm{K} \text { value } 3\end{array}$ \\
\hline $\begin{array}{c}\text { Micrograms } \\
5 \\
10 \\
15 \\
20 \\
25 \\
30 \\
50 \\
100 \\
150 \\
200 \\
250 \\
300\end{array}$ & $\begin{array}{l}3 \\
4 \\
5 \\
5 \\
5 \\
5 \\
2 \\
4 \\
4 \\
3 \\
2 \\
3 \\
3\end{array}$ & $\begin{array}{ll}96^{2}, & 963 \\
93^{2}, & 93^{3} \\
89^{3}, & 90^{0} \\
87^{0}, & 87^{1} \\
84^{\circ}, & 84^{2} \\
81^{0}, & 81^{2} \\
69^{2}, & 70^{0} \\
48^{0}, & 48^{2} \\
32^{2}, & 33^{0} \\
22^{3}, & 23^{0} \\
15^{3}, & 16^{0} \\
12^{\circ}, & 12^{1}\end{array}$ & $\begin{array}{l}0.0155 \\
0.0281 \\
0.0470 \\
0.0605 \\
0.0757 \\
0.0915 \\
0.1580 \\
0.3190 \\
0.4850 \\
0.6430 \\
0.8030 \\
0.9210\end{array}$ & $\begin{array}{l}0.0031 \\
0.0030 \\
0.0031 \\
0.0030 \\
0.0030 \\
0.0031 \\
0.0032 \\
0.0032 \\
0.0032 \\
0.0032 \\
0.0032 \\
0.0031\end{array}$ \\
\hline & & & Average & 0.0031 \\
\hline
\end{tabular}

1 These values correspond to the maximal pink colour produced when taken with a centre setting of $76^{1}$.

2 This is analogous to optical density as measured on a spectrophotometer and corresponds to the quantity $(2-\log 10$ of the galvanometer reading).

3 These values are obtained by dividing the photometric density by the amount of the gold in the test solution.

\section{Recovery of Gold from Urine, Blood Plasma, and Tissue}

The results obtained by the addition of known quantities of gold chloride to various volumes of urine and blood plasma as well as to various tissues are summarized in Tables 2 and 3 . In the case of urine, the percentage of recovery varied from $94 \cdot 2$ to 100 . The dilution of the urinary digest overcomes any inhibitory effect of inorganic salts on the development of the colour as found by Pollard
(1937). This is well illustrated by our results where the percentage of recovery is approximately the same for $50 \mathrm{c.cm}$. of urine as in $10 \mathrm{c.cm}$., although the concentration of inorganic salts is 5 times as great in the former. In blood, however, the error was slightly greater with the range of the percentage recovery being $84 \cdot 2$ to 100 . The greatest error in the

TABLE 2

Recovery of known amounts of Gold Chloride added to Urine and Plasma

\begin{tabular}{|c|c|c|c|c|c|}
\hline $\begin{array}{c}\text { Material } \\
\text { used }\end{array}$ & Volume & $\begin{array}{l}\text { Gold } \\
\text { added }\end{array}$ & $\begin{array}{l}\text { Colori- } \\
\text { meter }\end{array}$ & Gold fo & ound \\
\hline 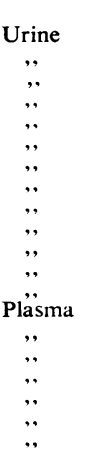 & $\begin{array}{c}\text { c.cm. } \\
10 \\
10 \\
10 \\
10 \\
10 \\
10 \\
50 \\
50 \\
50 \\
50 \\
50 \\
50 \\
50 \\
1 \\
1 \\
1 \\
1 \\
1 \\
1 \\
1\end{array}$ & $\begin{array}{r}\text { micrograms } \\
0 \\
20 \\
50 \\
150 \\
200 \\
250 \\
0 \\
10 \\
15 \\
20 \\
25 \\
50 \\
100 \\
0 \\
3 \\
5 \\
7 \\
8 \\
10 \\
20\end{array}$ & $\begin{array}{l}76^{0} \\
86^{3} \\
700 \\
34^{1} \\
25^{0} \\
17^{3} \\
76^{1} \\
93^{2} \\
90^{0} \\
86^{3} \\
840 \\
70^{2} \\
490 \\
76^{0} \\
890 \\
81^{3} \\
75^{1} \\
71^{1} \\
631 \\
40^{0}\end{array}$ & $\begin{array}{c}\text { micrograms } \\
0 \cdot 0 \\
19 \cdot 90 \\
49 \cdot 97 \\
150 \cdot 00 \\
194 \cdot 20 \\
242 \cdot 26 \\
0.0 \\
9 \cdot 42 \\
14 \cdot 77 \\
19 \cdot 90 \\
24 \cdot 42 \\
48 \cdot 97 \\
100 \cdot 00 \\
0.0 \\
2 \cdot 53 \\
4 \cdot 38 \\
6 \cdot 18 \\
7 \cdot 11 \\
9.95 \\
20.00\end{array}$ & $\begin{array}{c}\text { per cent. } \\
0 \cdot 0 \\
99 \cdot 5 \\
99 \cdot 9 \\
100 \cdot 0 \\
97 \cdot 1 \\
96 \cdot 9 \\
0 \cdot 0 \\
94 \cdot 2 \\
98 \cdot 5 \\
99 \cdot 5 \\
97 \cdot 6 \\
97 \cdot 9 \\
100 \cdot 0 \\
0 \cdot 0 \\
84 \cdot 2 \\
87 \cdot 6 \\
88 \cdot 3 \\
88.9 \\
99 \cdot 5 \\
900 \cdot 0\end{array}$ \\
\hline
\end{tabular}

TABLE 3

Recovery of Known Amounts of Gold Added to Tissues and Excreta of the White Rat

\begin{tabular}{|c|c|c|c|}
\hline \multirow{2}{*}{$\begin{array}{c}\begin{array}{c}\text { Material } \\
\text { used }\end{array} \\
\text { Heart . }\end{array}$} & \multirow{2}{*}{$\begin{array}{c}\text { Gold added } \\
\mathrm{mg} . \\
0.0 \\
0.010 \\
0.020 \\
0.030\end{array}$} & \multicolumn{2}{|c|}{ Gold found } \\
\hline & & $\begin{array}{l}\mathrm{mg} . \\
0.0 \\
0.00895 \\
0.01946 \\
0.02968\end{array}$ & $\begin{array}{c}\text { per cent. } \\
0.0 \\
89.5 \\
97.3 \\
98.9\end{array}$ \\
\hline Lung & $\begin{array}{l}0 \cdot 0 \\
0 \cdot 010 \\
0 \cdot 020 \\
0 \cdot 150\end{array}$ & $\begin{array}{l}0.0 \\
0.00928 \\
0.01973 \\
0 \cdot 1471\end{array}$ & $\begin{array}{r}0.0 \\
92.8 \\
98.7 \\
98.1\end{array}$ \\
\hline Spleen .. & $\begin{array}{l}0.0 \\
0.020 \\
0 \cdot 100 \\
0 \cdot 200\end{array}$ & $\begin{array}{l}0 \cdot 0 \\
0 \cdot 0199 \\
0 \cdot 100 \\
0 \cdot 1916\end{array}$ & $\begin{array}{c}0.0 \\
99.5 \\
100.0 \\
95.8\end{array}$ \\
\hline Liver & $\begin{array}{l}0.0 \\
0.200 \\
1.000 \\
5.000\end{array}$ & $\begin{array}{l}0.0 \\
0 \cdot 199 \\
0.971 \\
4.855\end{array}$ & $\begin{array}{r}0 \cdot 0 \\
99 \cdot 0 \\
97 \cdot 1 \\
97 \cdot 1\end{array}$ \\
\hline Kidney . . & $\begin{array}{l}0.0 \\
0 \cdot 100 \\
2.000 \\
5 \cdot 000\end{array}$ & $\begin{array}{l}0 \cdot 0 \\
0.958 \\
1.974 \\
4.855\end{array}$ & $\begin{array}{r}0 \cdot 0 \\
95 \cdot 8 \\
98 \cdot 7 \\
97 \cdot 1\end{array}$ \\
\hline Whole legs & $\begin{array}{c}0.0 \\
0.500 \\
5 \cdot 000 \\
20.000\end{array}$ & $\begin{array}{l}0.0 \\
0.4683 \\
4.797 \\
18.864\end{array}$ & $\begin{array}{r}0 \cdot 0 \\
93 \cdot 7 \\
95 \cdot 9 \\
94 \cdot 3\end{array}$ \\
\hline $\begin{array}{l}\text { Entire car- } \\
\text { case. }\end{array}$ & $\begin{array}{c}0.0 \\
2 \cdot 000 \\
10 \cdot 000 \\
40 \cdot 000\end{array}$ & $\begin{array}{c}0.0 \\
1.829 \\
9.870 \\
39.420\end{array}$ & $\begin{array}{r}0.0 \\
91 \cdot 5 \\
98.7 \\
98.5\end{array}$ \\
\hline Urine $1 \quad \ldots$ & $\begin{array}{c}0 \cdot 0 \\
0 \cdot 300 \\
5 \cdot 000 \\
10,000\end{array}$ & $\begin{array}{c}0 \cdot 0 \\
0 \cdot 294 \\
4 \cdot 813 \\
10 \cdot 000\end{array}$ & $\begin{array}{r}0.0 \\
98 \cdot 0 \\
96 \cdot 2 \\
100.0\end{array}$ \\
\hline Faeces ${ }^{1} \ldots$ & $\begin{array}{l}0.0 \\
0.500 \\
2.000 \\
5.000\end{array}$ & $\begin{array}{l}0.0 \\
0.4064 \\
1.987 \\
4.920\end{array}$ & $\begin{array}{r}0.0 \\
81.3 \\
99.3 \\
98.4\end{array}$ \\
\hline
\end{tabular}

1 Gold added to urine and faeces collected over a two-week period. 
case of plasma occurs in those instances in which less than 5 micrograms of gold are determined. For amounts greater than this there is essentially a 90 per cent. recovery. If a greater accuracy than 90 per cent. is desirable, a larger volume of plasma may be used. In tissues the recoveries vary from 90 to 100 per cent. except in one case in which $0.5 \mathrm{mg}$. of gold was added to faeces. In this instance recovery was $81 \cdot 3$ per cent. This comparatively low recovery is probably associated with the inhibition of colour development due to the presence of large amounts of inorganic salts in relation to the small quantity of added gold.

The specificity of the method in both urine and blood is shown by the colorimeter reading of 76 (Table 2) secured for digests of both urine and plasma. This value is identical to that secured with reagents alone. The same specificity is shown in the case of tissues where no gold was found when none was added. These results indicate that the intensity of the colour secured with these materials when they contain gold is due entirely to the presence of the gold and cannot be attributed to the reaction of the dye with any other inorganic salt.

\section{Summary}

An accurate and specific microcolorimetric method for the determination of gold by the use of the Evelyn photoelectric colorimeter has been described. The method is based upon the production of a stable red colour by the reaction between auric chloride and dianisidine in an acid medium in the presence of potassium fluoride. The method is applied to the determination of gold in urine and tissues in the range of 5 to 300 micrograms, and to blood plasma in the range of 5 to 30 micrograms.

\section{REFERENCES}

Cadwell, S. M., and Leavell, G. (1919). J. Amer. chem. Soc., 41, 1. Hansborg, H. (1925). Acta. tubercul. Scand., 1, 256.

Hartfall, S. G., Garland, H. G., and Goldie, W. (1937). Lancet, 2,784 .

Jamieson, A. R., and Watson, R. S. (1938). Analyst, 63, 702.

in

Kul'berg, L. M. (1936). Zavodskaya Lab., 5, 170; Chem. Abst. i 30, 4782.

Leulier, A., Bernard, G., and Loisy, P. (1937). J. Pharm. Chim., 25, 193.

Lombolt, S. (1926). Biochem. Z., 172, 141.

Merejkovsky, B. K. (1933). Bull. Soc. Chim. Biol., 15, 1336.

Peterson, H. (1898). Z. anorg. Chem., 19, 59.

Pollard, W. B. (1937). Analysi, 62, 597.

Stanbury, S. (1932). Tubercle, 13, 396.

Tukats, S. (1933). Biochem. Z., 260, 143. 